\title{
PEMBUATAN ASAM OKSALAT DARI PELEPAH KELAPA SAWIT (Elaeis guineensis) DENGAN KALSIUM HIDROKSIDA
}

\author{
Iloan Pandang H M, Yos Pawer Ambarita, Seri Maulina \\ Departemen Teknik Kimia, Fakultas Teknik, Universitas Sumatera Utara, \\ Jl. Almamater Kampus USU, Medan 20155, Indonesia \\ Email : iloanph_manalu@yahoo.com
}

\begin{abstract}
Abstrak
Pelepah kelapa sawit merupakan limbah padat yang memiliki kandungan selulosa tinggi. Pengolahan lebih lanjut terhadap pelepah kelapa sawit mampu menghasilkan produk yang bernilai ekonomi tinggi seperti asam oksalat. Tujuan dari penelitian ini adalah untuk mengkaji pengaruh konsentrasi kalsium hidroksida $\left(\mathrm{Ca}(\mathrm{OH})_{2}\right)$ dan waktu reaksi terhadap yield asam oksalat yang dihasilkan dari pelepah kelapa sawit. Penelitian ini dilakukan dalam dua tahap. Tahap pertama adalah preparasi pelepah kelapa sawit sehingga siap untuk digunakan. Tahap kedua adalah tahap pelaksanaan yang meliputi proses peleburan, filtrasi, dan kristalisasi. Analisis terhadap asam oksalat yang dihasilkan meliputi analisis kuantitatif berupa yield dan analisis kualitatif menggunakan Fourier Transform Infra Red (FTIR) dan plat melting point apparatus. Dari hasil penelitian diperoleh yield maksimum asam oksalat pada konsentrasi $\mathrm{Ca}(\mathrm{OH})_{2}$ 3,5 $\mathrm{N}$ dan waktu peleburan 60 menit yaitu sebesar 6,07\% didasarkan atas berat pelepah kelapa sawit. Hasil analisis kualitatif menunjukkan bahwa vibrasi gugus fungsi telah mendekati asam oksalat standar dengan titik leleh sebesar $106,2{ }^{\circ} \mathrm{C}$
\end{abstract}

Kata Kunci : asam oksalat, pelepah kelapa sawit, peleburan alkali, selulosa

\begin{abstract}
Palm frond is the solid waste which is high in cellulose. Further processing of palm frond is capable of producing high quality product such as oxalic acid. The aim of this research was to obtain the effect of calcium hydroxide $\left(\mathrm{Ca}(\mathrm{OH})_{2}\right)$ concentration and reaction time on the yield of oxalic acid produced with palm frond as raw material. This study was done with two steps. The first step was the preparation of palm frond until it was ready to be used. The second step was the conversion step which consists of fusion, filtration and crystallization. Oxalic acid produced was then analyzed with quantitative analysis of yield percentage and qualitative analysis using Fourier Transform Infra Red (FTIR) spectroscopy and plat melting point apparatus. The result showed that the maximum yield of oxalic acid was achieved at $\mathrm{Ca}(\mathrm{OH})_{2}$ concentration of $3.5 \mathrm{~N}$ and reaction time of 60 minutes, the value was $6.07 \%$ based on weight of palm frond. The qualitative analysis showed that the vibration of functional groups had approached the standard oxalic acid with the melting point was $106.2^{\circ} \mathrm{C}$.
\end{abstract}

Keywords : oxalic acid, palm frond, alkali fusion, cellulose

\section{Pendahuluan}

Indonesia merupakan negara penghasil kelapa sawit terbesar di dunia [10]. Hingga tahun 2014, luas perkebunan kelapa sawit di Indonesia sekitar 6,40 juta hektar [1]. Selain minyak, banyak limbah biomassa juga dihasilkan dari industri perkebunan kelapa sawit salah satunya adalah pelepah kelapa sawit [7]. Dalam setiap hektar perkebunan kelapa sawit, terdapat sekitar 145 pohon kelapa sawit. Setiap pohon kelapa sawit mampu menghasilkan sekitar 25 pelepah kelapa sawit dengan berat sekitar $8 \mathrm{~kg}$ per pelepah. Dengan demikian, sekitar 30 ton pelepah kelapa sawit mampu dihasilkan dari setiap hektar perkebunan kelapa sawit setiap tahunnya. Besarnya jumlah pelapah kelapa sawit yang dihasilkan merupakan suatu potensi untuk diolah lebih lanjut menjadi produk bernilai ekonomi yang mampu memberikan kontribusi positif bagi industri perkebunan kelapa sawit [16].
Selulosa merupakan komponen terbesar dalam pelepah kelapa sawit. Komponen ini dapat dikonversi menjadi produk bernilai ekonomi tinggi seperti asam oksalat. Asam oksalat memiliki banyak kegunaan antara lain dalam industri pengolahan dan pelapisan logam, pewarnaan serat, dan pembersih. Kebutuhan asam oksalat di Indonesia cukup tinggi setiap tahunnya dan hingga saat ini masih diimpor [14].

Asam oksalat dapat disintesis dari selulosa melalui metode peleburan alkali. Alkali yang umum digunakan adalah $\mathrm{NaOH}$ dan $\mathrm{Ca}(\mathrm{OH})_{2}$. Pada penelitian ini alkali yang digunakan adalah $\mathrm{Ca}(\mathrm{OH})_{2}$. Penggunaan $\mathrm{Ca}(\mathrm{OH})_{2}$ dalam proses peleburan diharapkan dapat mempersingkat tahapan pembuatan asam oksalat dibandingkan penggunaan $\mathrm{NaOH}$. Tahapan peleburan dan pengendapan dapat digabungkan sehingga efisiensi pembuatan asam oksalat akan meningkat baik dari segi teknis maupun ekonomis [13]. 


\section{Teori}

Pelepah kelapa sawit merupakan limbah biomassa yang dihasilkan dari pemangkasan kelapa sawit [8]. Komponen-komponen kimia utama pelepah kelapa sawit terdiri dari selulosa, hemiselulosa dan lignin. Kadar selulosa yang terdapat dalam pelepah kelapa sawit sekitar $35,88 \%$ [11].

Selulosa merupakan penyusun utama kayu yang berwarna putih dan tidak larut dalam air maupun dalam pelarut organik [13]. Struktur selulosa terdiri dari banyak ikatan gugus glukosa dalam bentuk unit $\beta$-D-anhydroglucopyranose (AGUs). AGUs dihubungkan satu sama lain melalui jembatan glikosidik pada karbon atom $\mathrm{C} 1$ dan C4. Jumlah pengulangan AGUs didefinisikan sebagai derajat polimerisasi (DP) selulosa. Secara umum, DP selulosa bervariasi sesuai dengan jenis asli bahan [17].

Asam oksalat (HOOC-COOH) atau asam etanadioat dengan berat molekul 90,04 g/mol adalah asam dikarboksilat paling sederhana, larut dalam air dan bersifat asam kuat. Asam ini tidak berbentuk anhidrat di alam dan secara komersial tersedia dalam bentuk padatan, asam oksalat dihidrat $\left(\mathrm{C}_{2} \mathrm{H}_{2} \mathrm{O}_{4} \cdot 2 \mathrm{H}_{2} \mathrm{O}\right)$ dengan berat molekul $126,07 \mathrm{~g} / \mathrm{mol}$.

Asam oksalat terdistribusi secara luas dalam bentuk garam potasium dan kalsium yang terdapat pada tumbuhan seperti bayam, jeruk teh, coklat, buncis, belimbing dan lain-lain [6]. Asam oksalat banyak digunakan sebagai bahan pemutih dalam bidang obat-obatan dan serat, pengolahan air limbah, sebagai agen reduksi untuk fotografi dan penghapusan tinta, penghapusan noda karat dari meja dapur, perlengkapan pipa dan kain, pewarna modren untuk bahan celup [9]. Dalam penggunaan sintetis organik, asam oksalat digunakan dalam memproduksi resin, pembuatan bubuk urea-formaldehida, katalis butadiena, dalam memproduksi bakteriofag, persiapan bahan baku untuk kapasitor porselen dan deterjen peralatan elektronik dan pengolahan limbah fotokatalitik [6]. Asam oksalat juga digunakan dalam industri minyak dan gas dan pabrik gula [9].

Asam oksalat dapat dihasilkan dari bahanbahan berselulosa dengan metode peleburan alkali. Pembuatan asam oksalat dari bahan yang mengandung selulosa dengan metode peleburan alkali berupa $\mathrm{NaOH}$ meliputi beberapa tahapan yaitu :

1. Tahap peleburan :

$$
\begin{aligned}
& \left(\mathrm{C}_{6} \mathrm{H}_{10} \mathrm{O}_{5}\right)_{\mathrm{n}}+4 \mathrm{n} \mathrm{NaOH}+3 \mathrm{n} \mathrm{O}_{2} \longrightarrow \\
& \mathrm{n}(\mathrm{COONa})_{2}+\mathrm{n}\left(\mathrm{CH}_{3} \mathrm{COONa}\right)+\mathrm{n}(\mathrm{HCOONa}) \\
& +5 \mathrm{n} \mathrm{H}_{2} \mathrm{O}+\mathrm{n} \mathrm{CO}_{2}
\end{aligned}
$$

2. Tahap pengendapan dengan $\mathrm{CaCl}_{2}$ :

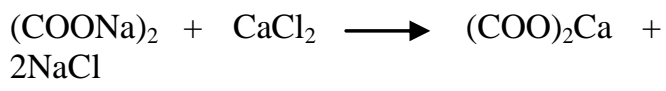

3. Tahap pengasaman dengan $\mathrm{H}_{2} \mathrm{SO}_{4}$ dan pengkristalan :

$(\mathrm{COO})_{2} \mathrm{Ca}+\mathrm{H}_{2} \mathrm{SO}_{4}+3 \mathrm{H}_{2} \mathrm{O} \longrightarrow(\mathrm{COOH})_{2}$ $+\mathrm{CaSO}_{4}$

Penggunaan jenis alkali berupa $\mathrm{Ca}(\mathrm{OH})_{2}$ pada proses peleburan dapat mengurangi tahap pengendapan dengan $\mathrm{CaCl}_{2}$, karena senyawa oksalat hasil dari proses peleburan telah diikat oleh ion $\mathrm{Ca}^{2+}$ dari $\mathrm{Ca}(\mathrm{OH})_{2}$ yang berlangsung secara simultan dengan proses peleburan tersebut. Tahapan proses pembuatan asam oksalat dengan menggunakan $\mathrm{Ca}(\mathrm{OH})_{2}$ adalah sebagai berikut [13]:

1. Tahap peleburan

$\left(\mathrm{C}_{6} \mathrm{H}_{10} \mathrm{O}_{5}\right)_{\mathrm{n}}+3 \mathrm{n} \mathrm{Ca}(\mathrm{OH})_{2}+2 \mathrm{n} \mathrm{O}_{2} \longrightarrow$
$\mathrm{n}(\mathrm{COO})_{2} \mathrm{Ca}+\mathrm{n}\left(\mathrm{CH}_{3} \mathrm{COOCa}\right)+\mathrm{n} \mathrm{HCOOCa}$
$+6 \mathrm{n}_{2} \mathrm{O}+\mathrm{n} \mathrm{CO}_{2}$

2. Tahap pengasaman

$(\mathrm{COOH})_{2}+\mathrm{H}_{2} \mathrm{SO}_{4} \longrightarrow(\mathrm{COO})_{2} \mathrm{Ca}+\mathrm{CaSO}_{4}$

\section{Metodologi Penelitian}

Bahan-bahan yang digunakan dalam penelitian ini yaitu pelepah kelapa sawit, kalsium hidroksida $\left(\mathrm{Ca}(\mathrm{OH})_{2}\right)$, asam sulfat $\left(\mathrm{H}_{2} \mathrm{SO}_{4}\right)$, etanol $\left(\mathrm{C}_{2} \mathrm{H}_{5} \mathrm{OH}\right)$ dan aquadest $\left(\mathrm{H}_{2} \mathrm{O}\right)$. Sedangkan peralatan yang digunakan antara lain labu leher tiga, hot plate, kondensor, oven, dan ball mill.

Preparasi Pelepah Kelapa sawit

Pelepah kelapa sawit dipotong kecil-kecil untuk mempercepat proses pengeringan. Kemudian dikeringkan dalam oven pada suhu 105 ${ }^{\circ} \mathrm{C}$ selama 30 menit. Selanjutnya dimasukkan ke dalam desikator selama 10 menit dan ditimbang. Pengeringan dilakukan hingga berat pelepah kelapa sawit konstan. Pelepah kelapa sawit yang telah kering kemudian dihaluskan dengan ball mill dan diayak menggunakan ayakan 50 mesh.

\section{Tahap Pelaksanaan}

Pelepah kelapa sawit kering sebanyak 15 gram yang telah diayak dengan ayakan 50 mesh dimasukkan ke dalam labu leher tiga dan ditambahkan dengan $250 \mathrm{ml}$ larutan $\mathrm{Ca}(\mathrm{OH})_{2}$ dengan konsentrasi tertentu. Lalu dipanaskan di atas hot plate pada suhu $95-100{ }^{\circ} \mathrm{C}$ selama waktu tertentu dengan pengadukan $225 \mathrm{rpm}$. Bahan didinginkan selama 10 menit, lalu disaring dan dicuci dengan aquadest panas hingga filtratnya jernih. Bahan dilarutkan dengan $\mathrm{H}_{2} \mathrm{SO}_{4} 4 \mathrm{~N}$ sebanyak $100 \mathrm{ml}$, dan didiamkan selama 24 jam 
sampai terbentuk endapan kalsium sulfat. Endapan disaring dan dicuci menggunakan $15 \mathrm{ml}$ etanol 96\%. Filtrat dipanaskan di atas waterbath pada temperatur $70{ }^{\circ} \mathrm{C}$ selama 1 jam. Filtrat didinginkan selama 24 jam sampai terbentuk endapan asam oksalat yang berupa kristal jarum berwarna putih. Hasil yang diperoleh dimurnikan dengan proses rekristalisasi menggunakan pelarut etanol $96 \%$.

Analisis Bahan Baku dan Produk

Analisis terhadap pelepah kelapa sawit meliputi analisis kadar air dengan metode Oven dan selulosa dengan metode Chesson. Sedangkan analisis terhadap asam oksalat yang dihasilkan meliputi analisis yield, titik leleh dan FTIR.

\section{Hasil dan Pembahasan}

Analisis Kadar Air dan Kadar Selulosa Pelepah Kelapa Sawit

Bahan baku pelepah kelapa sawit yang digunakan dalam penelitian ini mengandung kadar air sebesar $81 \%$. Kadar air yang tinggi mengakibatkan pelepah kelapa sawit dalam keadaan keadaan kering menjadi sangat ringan. Semakin tinggi kadar air akan menghasilkan persentasi biomassa yang semakin rendah atau dengan kata lain kadar air pelepah kelapa sawit berbanding terbalik dengan kandungan biomassa [3]. Sedangkan dari hasil analisis kadar selulosa, pelepah kelapa sawit mengandung selulosa sebesar $31 \%$. Semakin tinggi kadar selulosa maka yield asam oksalat yang dihasilkan akan semakin besar [5].

\section{Analisis Yield}

Yield asam oksalat didefenisikan sebagai [4]:

$$
\text { Yield }=\frac{\text { massa asam oksalat }}{\text { massa pelepah kelapa sawit }} \times 100 \%
$$

Yield asam oksalat yang dihasilkan dari pelepah kelapa sawit dengan metode peleburan alkali disajikan dalam grafik seperti pada Gambar 1 berikut.

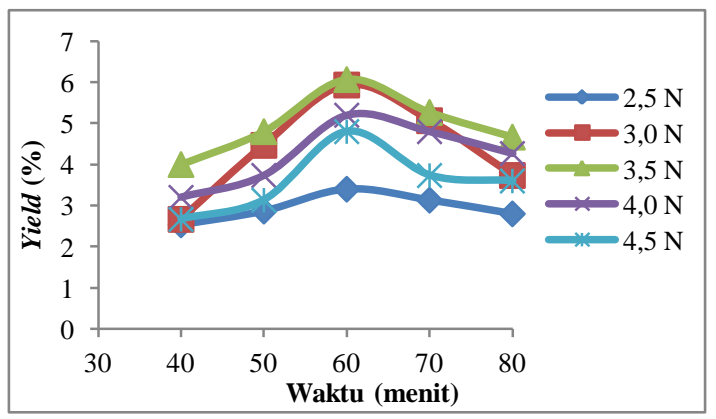

Gambar 1. Grafik hubungan waktu peleburan dan konsentrasi $\mathrm{Ca}(\mathrm{OH})_{2}$ terhadap yield asam oksalat
Gambar 1 menunjukkan pengaruh waktu peleburan dan konsentrasi $\mathrm{Ca}(\mathrm{OH})_{2}$ terhadap yield asam oksalat yang dihasilkan. Pada waktu peleburan 40 menit yield asam oksalat yang diperoleh cenderung tidak jauh berbeda pada berbagai variasi konsentrasi $\mathrm{Ca}(\mathrm{OH})_{2}$ akibat kecilnya kesempatan antar molekul untuk saling bertumbukan. Tetapi dengan bertambahnya waktu reaksi perbedaan yield semakin besar, hal ini memperlihatkan bahwa kenaikan waktu reaksi akan memberikan kesempatan reaktan saling bertumbukan semakin besar. Namun waktu reaksi yang terlalu lama juga mengakibatkan penurunan yield asam oksalat. Hal ini terlihat dengan semakin kecilnya yield asam oksalat yang diperoleh ketika melebihi waktu reaksi 60 menit. Penurunan yield ini kemungkinan disebabkan oleh terjadinya dekomposisi oksalat menjadi komponen lain yang lebih kecil seperti format dan $\mathrm{CO}_{2}$ [2]. Di sisi lain, peningkatan konsentrasi $\mathrm{Ca}(\mathrm{OH})_{2}$ hingga waktu reaksi 60 menit juga mengakibatkan peningkatan yield asam oksalat. Hal ini menunjukkan bahwa semakin besar konsentrasi larutan $\mathrm{Ca}(\mathrm{OH})_{2}$ maka selulosa yang dilebur akan semakin banyak sehingga yield asam oksalat juga semakin meningkat. Larutan dengan konsentrasi besar mengandung molekul-molekul yang lebih banyak sehingga lebih mudah bertumbukan dengan molekul-molekul yang jumlahnya sedikit [2]. Namun peningkatan konsentrasi $\mathrm{Ca}(\mathrm{OH})_{2}$ yang melebihi 3,5 N justru mengakibatkan penurunan yield asam oksalat. Hal ini kemungkinan disebabkan konsentrasi $\mathrm{Ca}(\mathrm{OH})_{2}$ yang terlalu tinggi mengakibatkan komponen lain dalam pelepah kelapa sawit seperti hemiselulosa ikut bereaksi. Reaksi ini cenderung lambat akibat hemiselulosa yang kurang reaktif dibandingkan dengan selulosa [15]. Akibatnya yield asam oksalat masih mengalami peningkatan hingga waktu reaksi 60 menit, meskipun perolehannya semakin kecil dibandingkan konsentrasi sebelumnya.

\section{Analisis FTIR}

Karakteristik FTIR asam oksalat standar dan hasil sintesis dapat dilihat pada Gambar 2 dan 3 berikut.

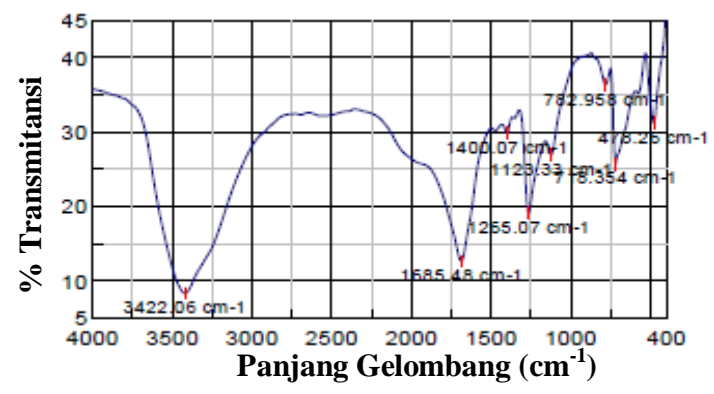

Gambar 2. Karakteristik FTIR asam oksalat standar [14] 


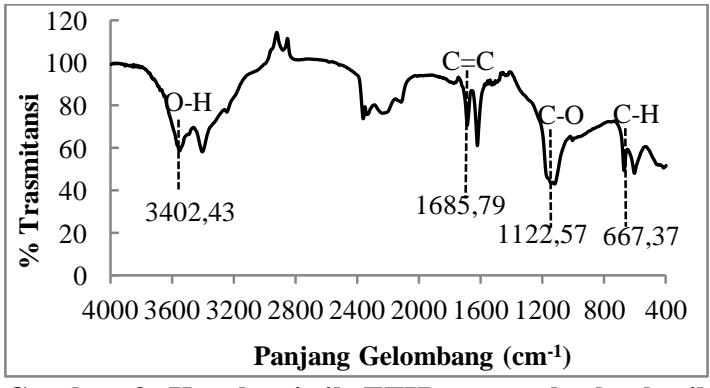

Gambar 3. Karakteristik FTIR asam oksalat hasil sintesis

Analisis FTIR (Fourier Transorm Infra Red) bertujuan untuk mengidentifikasi gugus fungsi dari suatu senyawa pada panjang gelombang tertentu. Spektrum FTIR asam oksalat pada Gambar 3 menunjukkan adanya gugus $\mathrm{OH}, \mathrm{C}=\mathrm{C}$, $\mathrm{C}-\mathrm{O}$, dan $\mathrm{C}-\mathrm{H}$. Gugus hidroksil $(\mathrm{O}-\mathrm{H})$ asam oksalat sintesis dikarakterisasi pada bilangan gelombang $3402,43 \mathrm{~cm}^{-1}$ sedangkan asam oksalat standar memiliki serapan kuat pada bilangan gelombang 3200-3700 $\mathrm{cm}^{-1}$ dengan serapan kuat dan tajam pada $3422,06 \mathrm{~cm}^{-1}$. Gugus-gugus lain juga juga diperoleh hal yang sama. Gugus $\mathrm{C}=\mathrm{C}$ dengan bilangan gelombang $1685,48 \mathrm{~cm}^{-1}$ pada asam oksalat standar dan $1685,79 \mathrm{~cm}^{-1}$ pada asam oksalat hasil sintesis. Gugus C-O dengan bilangan gelombang $1123,33 \mathrm{~cm}^{-1}$ pada asam oksalat standar dan $1122,57 \mathrm{~cm}^{-1}$ pada asam oksalat hasil analisis. Gugus C-H dengan bilangan gelombang $718,35 \mathrm{~cm}^{-1}$ pada asam oksalat standar dan 667,37 $\mathrm{cm}^{-1}$ pada asam oksalat hasil sintesis. Vibrasi regangan antara asam oksalat standar dengan asam oksalat hasil sintesis memiliki puncak yang tidak jauh berbeda. Hal ini membuktikan bahwa dalam penelitian ini, senyawa yang dihasilkan merupakan asam oksalat. Namun asam oksalat tersebut belum murni karena masih terdapat puncak-puncak lain yang bukan puncak spesifik dari asam oksalat.

\section{Analisis Titik Leleh}

Penentuan titik leleh adalah salah teknik paling sederhana dalam mengidentifikasi suatu zat kimia. Titik leleh merupakan karakteristik fisika yang memberikan informasi mengenai ciri dan kemurnian suatu bahan kimia [12]. Kristal asam oksalat yang dihasilkan memiliki titik leleh sebesar $106,2^{\circ} \mathrm{C}$. Sedangkan asam oksalat standar memiliki titik leleh sebesar $101,5{ }^{\circ} \mathrm{C}$ [6]. Perbedaan ini disebabkan karena adanya pengotor dalam asam oksalat hasil sintesis.

\section{Kesimpulan}

Asam oksalat dapat disintesis dari pelepah kelapa sawit dengan metode peleburan alkali. Yield asam oksalat tertinggi diperoleh pada konsentrasi $\mathrm{Ca}(\mathrm{OH})_{2} 3,5 \mathrm{~N}$ dan waktu peleburan 60 menit. Asam oksalat yang dihasilkan memiliki karaktersitik FTIR yang mendekati asam oksalat standar dengan titik leleh sebesar $106,2^{\circ} \mathrm{C}$.

\section{Daftar Pustaka}

[1] Badan Pusat Statistik, http://www.bps.go.id/linkTabelStatis/view/i d/1665, 2015, diakses pada 4 Agustus 2015.

[2] Endang Mastuti W., Pembuatan asam oksalat dari sekam padi, Ekuilibrium, 4, (2005), 13-17.

[3] Erwinsyah, Distribusi kadar air dan biomassa komponen tanaman kelapa sawit, J. Pen. Kelapa Sawit, 7, (2009), 59-65.

[4] F. Nababan, Zultiniar, dan S. Herman, Pengaruh kecepatan pengadukan terhadap hasil pada pembuatan asam oksalat dari bahan dasar ampas tebu, JOM FTEKNIK, 1, (2014), 1-7.

[5] J.D. Mane, S.J. Jadhav, and N.A. Ramsiah, Production of oxalic acid from dry powder of Parthenium hysterophorus L., J. Agric. Food Chem., 34, (1986), 989-990.

[6] Kirk \& Othmer, Encyclopedia of Chemical Technology, John Wiley and Sons Inc., New York, 2007.

[7] M.A.K.M. Zahari, M.R. Zakaria, H. Ariffin, M.N. Mokhtar, J. Salihon, Y. Shirai, and M.A. Hassan, Renewable sugars from oil palm frond juice as an alternative novel fermentation feedstock for value-added products, Bioresource Technology, 110, (2012), 566-571.

[8] M.A.K.M. Zahari, S.S.S. Abdullah, A.M. Roslan, H. Ariffin, Y. Shirai, and M.A. Hassan, Efficient utilization of oil palm frond for bio-based products and biorefinery, Journal of Cleaner Production, 65, (2013), 252- 260.

[9] M. Dakshene, A. Rani, and P.D. Sharma, Removal and kinetics of oxalic acid adsorption from aqueous waste over alkali activated power plant fly ash, International Journal of Chemical Studies, 1, (2013), 14120.

[10] M.F. Mohideen, M. Faiz, H. Salleh, H. Zakaria, and V.R. Raghavan, Proceedings of the World Congress on Engineering, London, U.K., 2011, vol. III.

[11] M.F. Putri, D.P. Sari, A. Caesari, dan G. Miranda, Biobleaching pelepah sawit sebagai bahan baku pembuatan nitroselulosa menggunakan enzim xylanase, Jurnal Teknik Kimia, 2, (2013), 10-17.

[12] M. Whetton , K. Baryla, and H. Finch, The effect of the choice of method for determining assigned value on the assessment of performance in melting point analysis, Accred Qual Assur, 17, (2012), 413-417. 
[13] P. Mardina, Norhayani, dan D. Triutami, Pembuatan asam oksalat dari sekam padi dengan hidrolisis berkatalisator $\mathrm{NaOH}$ dan $\mathrm{Ca}(\mathrm{OH})_{2}$, Jurnal Bahan Alam Terbarukan, 2, (2013), 7-13.

[14] S. Herman, S.R. Yenti, dan Khairat, Pengaruh konsentrasi $\mathrm{NaOH}$ pada proses pembuatan asam oksalat dari ampas tebu, Jurnal Teknobiologi, 4, (2013), 61-64.

[15] S. Kim, and M.T. Holtzapple, Lime pretreatment and enzymatic hydrolysis of corn stover, Bioresource Technology, 96, (2005), 1994-2006.

[16] T.M. Yun, I. Puspasari, S.M. Tasirin, M.Z.M. Talib, W.R.W. Daud, and Z. Yaakob, Drying of oil palm frond particles in a fluidized bed dryer with inert medium, Chemical Industry \& Chemical Engineering Quarterly, 19, (2013), 593-603.

[17] Y.B. Huang, and Y. Fu, Hydrolysis of cellulose to glucose by solid acid catalysts, Green Chemistry, 15, (2013), 1095-1111. 